\title{
GEOTECTONIC MODELS AND GEOLOGIC EVOLUTION OF THE HIGH-GRADE GNEISS TERRANES OF JUIZ DE FORA (MG), BRAZIL
}

\section{JOSÉ RENATO NOGUEIRA ${ }^{1}$ AND ASIT CHOUDHURI ${ }^{2}$}

\begin{abstract}
The orthogneisses of the Ribeira Belt, in the Juiz de Fora area, underwent a sequence of geologic processes during times previous to the Brasiliano orogeny that generated this belt. The present study intends to recover and to reconstitute the geological evolution related to these processes. The units are distributed in two main tectonic domains (JFTD and ANDTD) that were subdivided in three structural domains with specific characteristics.

The metamorphic studies point to the existence of two high-grade metamorphic peaks associated to two different tectonic events. The last event is related to the Brasiliano orogeny, with ages around 610-490 Ma and this affected the orthogneisses of the basement as well as Andrelândia Group supracrustal rocks, deposited between 1.0 and $0.6 \mathrm{Ga}$. The metamorphism related to the Transamazonian orogeny, dated at 2.2-1.9 Ga, affected only the basement orthogneisses. Peak P-T conditions for these events are considered to be $6-8 \mathrm{~kb} / 750-800^{\circ} \mathrm{C}$ and $4-6 \mathrm{~kb} / 800-850{ }^{\circ} \mathrm{C}$ respectively.

It is proposed that the tectonic evolution for the Transamazonian orogeny could result in crustal thickening by continuous subcontinental accretion (vertical) and consequent thinning of the lithospheric mantle, and generating this way a continental magmatic arc. The resulting anomalous heat flow would elevate the continental geotherms causing extensive partial melting and differentiation of the lower crust generating preferentially tonalitic magma, and later passing on to more granitic compositions. These magmas would ascend in the crust, reworking older segments (Archean?) in upper crustal levels.

The proposed geological evolution involves extensional processes with magmatic intra and underplating, during the Transamazonian orogeny, that provided $\mathrm{CO}_{2}$-rich fluids and the necessary heat for the granulite metamorphism. The final stage of the Transamazonian orogeny witnessed crustal thinning aided by erosion, which resulted in rifting of the upper crust, recorded by the intracratonic São João del Rei basin metasedimentary rocks. After a long period of quiescence, compressive continental collision processes took place during the Brasiliano orogeny and this juxtaposed the supracrustals and basement rocks. Intense anatetic processes in this period, removed large amounts of $\mathrm{H}_{2} \mathrm{O}$ from the system, enabling the metasedimentary rocks to attain granulite facies.
\end{abstract}

Keywords: high-grade gneiss; geotectonic; Transamazonian; orogeny

INTRODUCTION The study of high-grade gneiss terranes has played an important role in the understanding of many subjects related to the petrogenetic evolution of the crust during the geological time. The internal structures and relationships between the rock types are generally complex due to the long evolutionary history, which these rocks have undergone. This complex framework comes from a sequence of processes and geological events (deformation, intrusions, metamorphic phases, partial melting, recrystallization, and assimilation) that tend to obliterate older structures by printing new features in the rocks. This paper aims to approach the evolutionary history of a portion of the Ribeira Belt in the area of Juiz de Fora (MG), and also to propose and discuss models for the geotectonic evolution of the this belt in order to provide means to a better understanding of the complex polymetamorphic and multideformational processes.

GEOLOGY The studied area is made up of two main tectonic domains: i) Juiz de Fora Tectonic Domain - JFTD and ii) Andrelândia Tectonic Domain - ANDTD, that can be subdivided into three structural domains, each with singular tectonic characteristics (Fig. 1). Tectonic activity caused an intense intercalation between basement units essentially constituted by hornblende orthogneisses and orthogranulites and metasedimentary units composed of garnet-biotite gneisses, that are distributed between the two main tectonic domains.

Structural geology, metamorphism and fluid inclusion data (Nogueira 1999) indicate the existence of two different tectono-thermal events, which differ in pressure and temperature, and that affected the two main lithological groups, i.e. the basement (Juiz de Fora and Mantiqueira Complex) and metasedimentary rocks (Andrelândia Group), resulting in granulite facies mineralogical associations during both events. Metamorphism related to a tectonic event that only affected the orthogneiss basement rocks probably belongs to the Transamazonian orogeny, with ages between 2.2-1.9 Ga (Machado $e t$ al. 1996). The last event is certainly related to the Brasiliano/PanAfrican orogeny, with ages between 610-490 Ma (Machado et al. 1996) having affected the basement orthogneisses as much as the supracrustal rocks, the latter largely correlated to the Andrelândia Group that deposited between 1.0 and 0.6 Ga (Ribeiro et al. 1995).

\section{Metamorphism and Structural Framework}

The

metamorphism and P-T conditions point to two different granulite peaks. The older is ascribed to the Transamazonian orogeny, overprinted on the Mafic-Felsic Association rocks of the ANDTD, and the orthogneisses of JFTD at pressures between 4-6kb and temperatures between $800-850^{\circ} \mathrm{C}$ (Nogueira 1994). Coronitic textures observed in these granulitic rocks indicate isobaric cooling retrometamorphic paths, with the production of secondary garnet as borders, lamellae or granules in contact between orthopyroxene and plagioclase, or as intergrowths in pre-existing garnet.

The younger metamorphism that affected the metasedimentary rocks during the Brasiliano orogeny reached granulite facies with P-T intervals estimated at $6-8 \mathrm{~kb} / 750-800^{\circ} \mathrm{C}$ (Nogueira 1994). This Brasiliano age metamorphism culminated in extensive retrometamorphism in the basement rocks with the formation of hydrous minerals from $\mathrm{Fe}-\mathrm{Mg}$ minerals of the granulite facies. In the Archaean of Greenland, McGregor and Friend (1997) report such retrometamorphism of granulite facies rocks.

Structures generated by the Brasiliano orogeny were analyzed separately by structural domains. These domains show evidences of a progressive compressive tectonic setting, initially tangential, with NW vergence, culminating with the formation of lens shaped structures during the main directional phase. This evolution (Nogueira in prep.) is registered in the three structural domains studied. In the Domain I (Fig. 1), located in the north of the area, moved away from the focal area of the Paraíba do Sul Shear Zone (PSSZ) or Paraíba do Sul Tectonic Domain (Fig. 1). The relationships between stretching lineations and fold axes indicate the formation of b-type folds (Ramsay $\&$ Huber 1987), and imply an oblique frontal ramp, with tangential stresses toward the NW.

In the Structural Domain II, a transition from b-type to a-type folds indicates a more inclined oblique ramps with tectonic transport to $\mathrm{N}$, tending to NE. The structures of Domain III, closer to the focal zone of PSSZ, have anastomosed or lens shaped NE sub-horizontal axis structures, with the stretching lineation along the limbs of these lenses. The attitude of the fold axes is interpreted as the result of their rotation in the external parts of the lenses, resulting in a-type folds with axes adjacent to the two median planes related to the lenses. On the other hand, the occurrence of b-type folds within the lenses is represented by more vertical fold axes in the interior parts of this anastomosed structure. In this domain, the period associated to the directional tectonics can be considered as larger deformation intensity and therefore the most important.

The relationship between the described structures can be interpreted as a continuous evolution, where a tangential tectonic setting is 


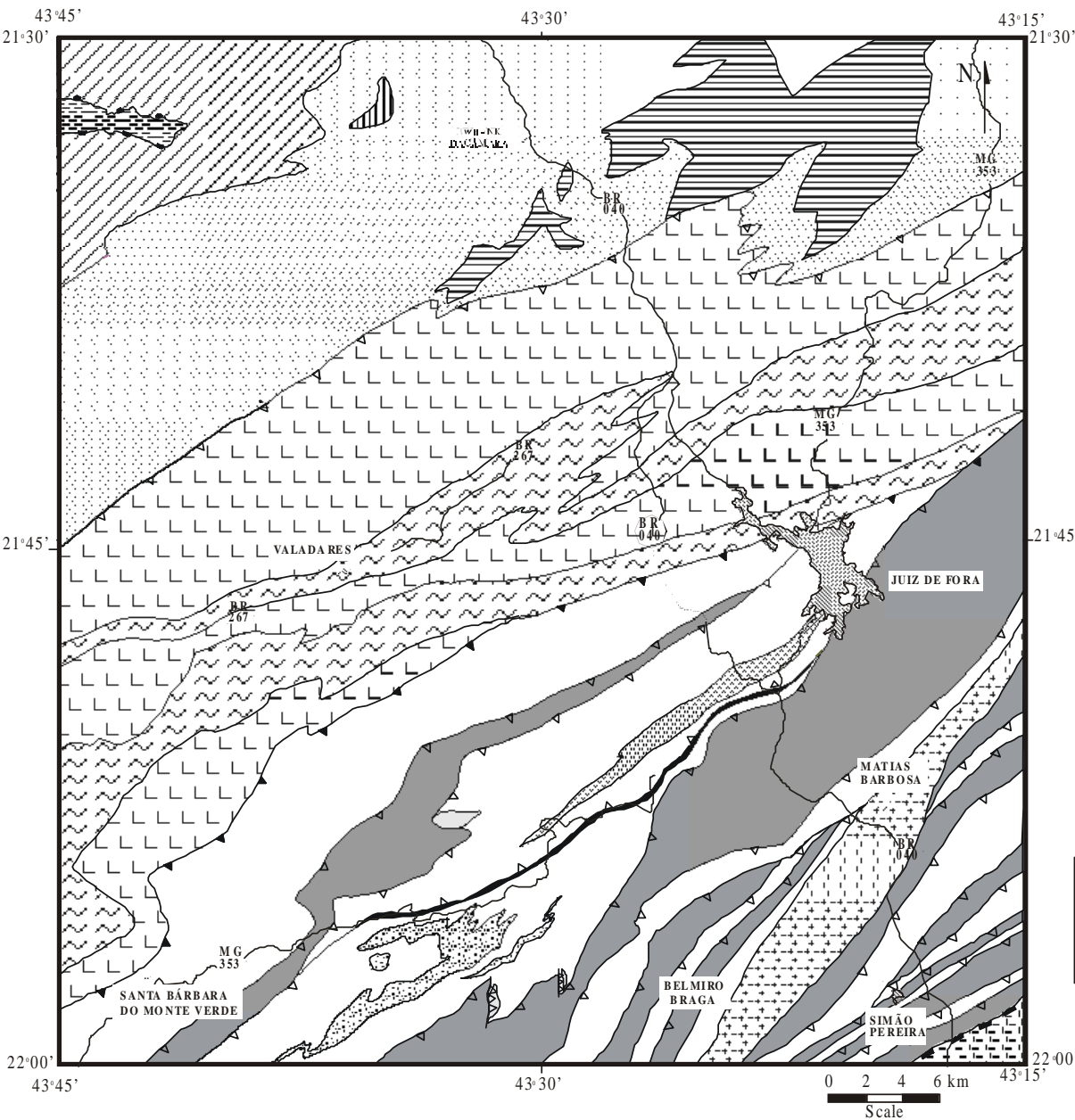

LITHOLOGICAL UNITS

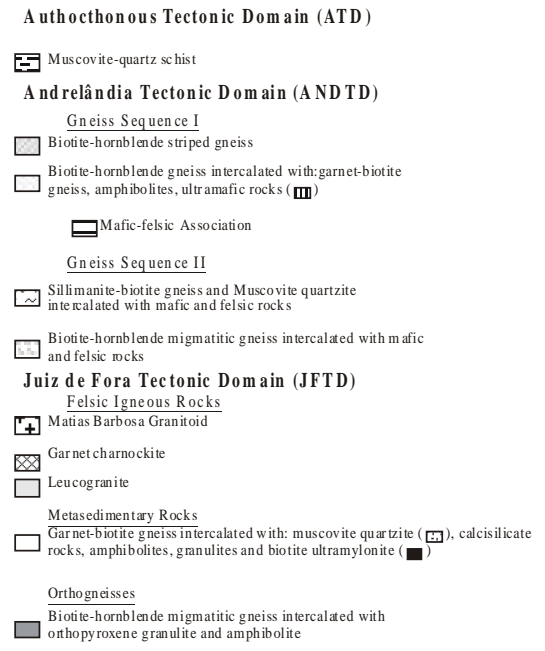

Paraíba do Sul Tectonic D om ain (PSTD)

Muscovite-biotite porfiritic granite (Quirino-D orândia Intrusive Suite) with
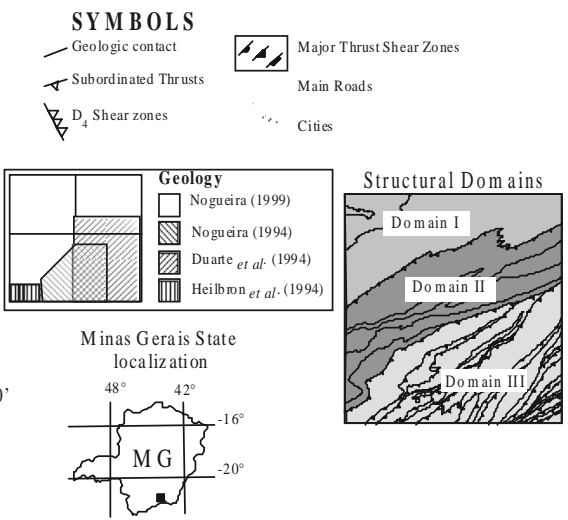

Figure 1 Detailed geological map of the Juiz de Fora area, Minas Gerais state.

gradually modified to another in which the directional tectonics prevail, both related to the $\mathrm{D}_{2}$ phase, culminating essentially with transcurrent movement during the $\mathrm{D}_{3}$ phase.

The analysis of the structural features formed before the Brasiliano orogeny, mainly in the Structural Domain I, reveal complex folds, in a general way delineating low angle fold limbs dipping to ENE and SSW, and axes also with gentle plunges to SE. Preferential N-S directional shear zones showing evidences of movement associated to extensional stresses occur related to these structures.

Fluid Inclusions and Geochemistry Fluid inclusions and geochemical data from the structural domains where basement rocks predominate, especially to the north of the area, indicate a complex evolution before the Brasiliano orogeny.

The fluid inclusion studies show that the basement rocks contain typical granulite facies inclusions, with moderate density $\mathrm{CO}_{2}$-rich fluid composition (81-93\% $\mathrm{CO}_{2}$ ), varying from 0.79 to $0.94 \mathrm{~g} / \mathrm{cm}^{3}$ (Nogueira et al. 1999). The fluid inclusion of the metasedimentary portion of JFTD have $92-100 \% \mathrm{CO}_{2}$ with moderate to high densities, between 0.916 and $1.068 \mathrm{~g} / \mathrm{cm}^{3}$ (Nogueira 1999).

The study of fluid inclusions in granulite facies metasedimentary supracrustal rocks of the Andrelândia Group showed that inclusions trapped during the $\mathrm{D}_{2}$ phase, corresponding to the Brasiliano metamorphic peak, have higher densities than those generated during the $\mathrm{D}_{3}$ phase, which in turn have higher densities than inclusions formed during the $\mathrm{D}_{4}$ phase. These facts point to a more significant decrease in pressure than the temperature after the granulite metamorphic peak, a feature in keeping with decompression that is approximately isothermal, with a clockwise P-T-t path for the Brasiliano orogeny (Nogueira 1999).

Relative chronology of fluid inclusions associated with granulite facies basement rocks, in the orthogneiss portions of JFTD revealed that the last formed inclusions (in trails) present systematically higher densities than the first inclusions to be trapped (isolated), possibly pointing to an anti-clockwise retrograde path during the Transamazonian orogeny, with approximately isobaric cooling (Nogueira et al. 1999).

Harley (1989), in a compilation for the retrograde path of several granulite terranes of the world, stipulated the more common P-T paths for the granulitic rocks. The division in isobaric cooling (IBC) and isothermal decompression (ITD) granulites is broadly used for granulite terranes after this work. Bohlen (1987) proposes that anticlockwise-IBC paths in granulites are caused by magmatic underplating beneath the continental crust, and intrusion and crystallization of substantial volumes of igneous materials within the crust. A continental magmatic arc environment was proposed as a likely tectonic regime in which such processes could take place; but hot spots or incipient rift environments (Sandiford \& Powell 1986) under certain circumstances might also yield IBC-type anti-clockwise paths. In accord with Harley (1989), ITD granulites are formed in crust thickened by collision, with magmatic additions as an important source of heat.

In order to evaluate the possible environments in which the protholiths of the basement orthogneisses of the ANDTD were generated, major and trace elements analyses of these rocks was carried out. Their compositions show that the analyzed rocks can be subdivided in two main sequences, tholeiitic and calc-alkaline, marked by some well defined trends and characteristic geochemical behaviors (Nogueira 1999).

In relation to the tholeiitic series, there is a compositional variation from intermediate to basic, with trace elements $\mathrm{Nb}$ and $\mathrm{V}$, besides Ti, Fe- and Mn-rich mineral phases (e.g. oxides) participation in the generated liquids. The calc-alkaline suite, composed basically of rocks of intermediary to acid composition, presents evidence that the most 
developed members (K-rich granites) have been formed under K-rich fluids metamorphic/magmatic conditions, which characterizes the evolution of the Brasiliano orogeny in the studied area.

Negative correlation between the oxides $\mathrm{CaO}$ and $\mathrm{MgO}$ in both suites points to a continuous removal process of these elements in plagioclase and clinopyroxene formation.

From multi-element diagram analysis together with diagrams related to tectonic settings, an intraplate origin for the tholeiitic rocks is suggested. In that case, magma generation under lower continental crust conditions, progressively evolving to the generation of magmas enriched in incompatible elements, is a reasonable possibility.

These basic liquids possibly evolved, initially still at under- and intra-plate conditions, to form intermediary to acid rocks of the calcalkaline suite, leading to the initial stages of a magmatic continental arc. It is also possible that the rocks generated in this magmatic arc have been later reworked during the Brasiliano orogeny, generating the $\mathrm{K}$-granites with syn-collisional characteristics.

\section{GEOTECTONIC MODELS From the geological characteristics}

\section{discussed above such as:}

i) structural evidences of extensional tectonics previous to Brasiliano orogeny;

ii) retrograde textures indicating isobaric cooling in basement granulites;

iii)fluid inclusions results suggesting an anti-clockwise-IBC P-T-t path also in basement granulites;

iv) chemical composition of basic rocks in accord with their origin in an intraplate setting, under lower continental crust conditions; with reference to Bohlen's (1987) affirmation that IBC granulites can be caused by magmatic underplating below an existent continental crust, with intrusion and crystallization of substantial magma volumes, it is possible that extensional tectonic processes could have occurred in the basement rocks, in a tectonic event previous to Brasiliano orogeny, and based on $\mathrm{U} / \mathrm{Pb}$ ages obtained by Machado et al. (1996), this event can be correlated with the Transamazonian orogeny. In relation to the Ribeira Belt, the calc-alkaline suites have been ascribed to a convergent tectonic setting, probably related to a Paleoproterozoic active margin (Heilbron 1993, Teixeira and Figueiredo 1991). The suggestion of a Paleoproterozoic reworking of an older segment of the continental crust has also been corroborated by more recent studies (e.g. Machado et al. 1996) that indicate Archean $\mathrm{U} / \mathrm{Pb}$ ages in inherited zircons. However, basic rocks, possibly related to extensional periods that affected the continental crust still remain undated.

Heilbron et al. (1997), focusing the lithogeochemistry of the orthogranulites of Juiz de Fora Complex, in the area between Rio Preto (MG) and Vassouras (RJ) propose a subdivision in two different tectonic associations. The first represented by two calc-alkaline series, geochemically similar to modern magmatic arcs; and the second, with two groups of basic rocks, one tholeiitic and another with transitional to alkaline basalts, both indicating extensive intracontinental setting. The authors also stressed the need for a geochronologic investigation for understanding the relationship between these different tectonic settings.

Some geotectonic models have been used to explain ambiguous results that define compressive and extensional settings in the same belt, in rocks apparently associated to the same tectonic event. This important discussion usually results from the lack of geological evidences and the difficulty in clarifying separately which rocks have participated on a given tectonic event in a mobile belt. In this sense the detailed geological mapping and studies of high-grade gneiss terranes are a source of important evidence in the discussion of geotectonic models of deep crustal processes that are as yet not well known.

These models can either represent tectonic history of one cycle, as in younger terranes, or terranes of polycyclic tectonic evolution, characteristic of most of the granulite terranes in shield areas (Ellis 1987, Harley 1989, Sandiford \& Powell 1986). Some tectonic processes can generate granulite facies P-T conditions in one tectonic cycle, as for example extension followed by continental crust thinning, even so, the granulite facies assemblages would remain buried in the middle-lower crust (Thompson \& England 1984). Thompson (1990) presents some possible tectonic processes, listed below, that can be the cause of granulite facies regional metamorphism, partial melting and sometimes exhumation of the continental crust:

(1)Continental collision followed by erosional thinning - In this model, the granulites would remain in the lower crust after erosion has returned the thickened crust back to its previous thickness, as only the upper crust has been eroded away.

(2) Continental collision followed by extensional thinning - In this hypothesis, extensional thinning would cause high temperature granulitic metamorphism in the lower crust in response to the massive injection of mantle derived magmas. Extensional thinning of the lower crust alone would not cause uplift of lower crustal granulites to the surface. Extensional thinning of the upper crust, along normal fault systems could expose mid-crustal granulites as tectonic windows.

(3) Continental collision with tectonic exhumation - This model requires large-scale faults or shear zone systems that can penetrate and be active over the whole crustal thickness. The pressure and temperature conditions preserved by the mineralogy clearly would depend upon when the tectonic exhumation occurred along the P$\mathrm{T}$ path and if the rate of exhumation was fast enough to cause freezing of the granulite facies assemblage.

(4) Multiple thickening of continental crust - Repeated thickening of overthickened crust would not produce a significant boost to the geotherms during subsequent crustal thinning by erosion or by extension, than would a single thickening event.

(5) Magmatic underplating - Massive injection in the lower crust by mantle-derived magmas would cause granulite facies conditions to be attained at depths determined by the levels of the massive intrusions, and over distances determined by the volume of the intrusives and the initial crustal geotherm. In this model, the mantle-derived magma would need to inject a crust undergoing extension and regional terranes of mid-crustal granulites could result.

(6) Crustal Delamination - Detachment of the lower lithosphere, which has become denser than adjacent mantle through mineral reactions, to be replaced by hot asthenosphere; this is a very effective way of achieving granulite P-T conditions in the lower continental crust. With the removal of the thickened continental root, there is no isostatic drive for erosional uplift. Thus exhumation of the lower crustal high-temperature granulite facies rocks so produced in the lower crust would need a later tectonic uplift.

From the above hypotheses, only model (5) require extensional tectonic conditions alone to generate granulites, but model (2) predicts both processes where continental collision is followed by extensional thinning. In these two models, magmatic underplating processes with intrusions of basic magmas in the base and in the lower crust can be considered important. In the first case, IBC granulites associated to an anti-clockwise metamorphic P-T-t path would require extension with crustal thickening as the only way to generate this path. The second model would generate a clockwise path associated to isobaric cooling related to the extensional thinning stage.

Clemens (1990) presents a model that takes into account the participation of under- and intra-plating mantle-derived magma in crustal growth. From that proposal of granulite production from fluidpresent or fluid-absent metamorphism, Clemens (1990) formulated an outline, where restitic granulites would be formed by fluid-absent partial melting of supracrustal rocks, surround the under- and intraplated mafic rocks. Cooling and crystallization of such near anhydrous basaltic magmas would provide the thermal energy required for partial melting of overlying (or surrounding), fertile, crustal rocks. Granitoid magmatism would be generated by basaltic mantle magmatism and a system of feeder dikes would have bled a melt fraction away from this zone to produce a high-level granitoid batholith. At mid-crustal levels, gabbroic pluton, aided by a small influx of $\mathrm{H}_{2} \mathrm{O}$, would cause local, fluid-present, partial melting of the surrounding amphibolite facies rocks. The products would be a migmatitic zone and a small diapir of feebly mobile, restite-rich granite.

According to Touret (1992), magma stacking at the base of the crust would result in a simultaneous increase of pressure and temperature, leading to a general P-T evolution characterized by an anti-clockwise path, typical for most granulites (Bohlen 1987, Harley 1989). Granulitic metamorphism is caused by a vertical accretion of the con- 
tinental crust due to successive intrusions in the base. In some cases, these conditions remain for a long period of time and great amounts of magmas are episodically added. The proposed model emphasizes the simultaneous development of granulites in the lower crust and granites in the middle crust (fertile crust concept, Clemens 1990).

Alternatively, Smellie (1994), studying Cenozoic and present day tectonic environments, proposes a model where magmatic arc related volcanism in subduction zones is associated to extensional processes. This model demonstrates how the applied stress can be critically dependent if the subduction zone is locked, that is, with high degree of coupling, or unlocked. Thus, a compressional stress regime would occur in locked systems, and extensional stress in unlocked systems, and a gradient from compression in the fore-arc to extension in the back-arc is said to characterize partially locked systems.

From the above discussion, two geotectonic models are presented for Transamazonian orogeny that can explain the possible anticlockwise-IBC metamorphic path, the extensional tectonics detected in the granulites of Juiz de Fora Complex and the active margin convergent tectonic settings that result in magmatic arcs.

The first, proposed by Heilbron et al. (1997), visualizes the roots of an extensional Paleoproterozoic Cordilleran magmatic arc located at the border of an Archaean cratonic margin, as the result of the Transamazonian convergence. This model predicts both reworking of older continental crust and juvenile accretion followed by granulite facies metamorphism. In this case, the IBC path could suggest a long time of lower crustal residence. This proposal fits model (2) (Thompson 1990).

In the second model, proposed in this work, both magmatic suites described and the granulite facies metamorphism can be related to the same Transamazonian extensional tectonic event, with the formation of magmatic intra- and underplating, providing $\mathrm{CO}_{2}$-rich fluids and excess heat necessary for granulitic metamorphism.

In this continuous process, the intrusion of considerable volumes of basic magmas at the base and within the lower crust would cause a significant increase in the heat flow, enabling the beginning of partial melting of lower crustal rocks, possibly mainly basic in composition or even older granulites, and generating a large amount of magma probably of tonalitic to granitic composition. Partial melting and differentiation processes in these conditions would remove great amounts of $\mathrm{H}_{2} \mathrm{O}$ from the system and, together with upward flow of $\mathrm{CO}_{2}$-rich fluids from the mafic rocks, would cause extensive granulite metamorphism in these rocks.

Dewey (1988) affirms that the rate at which a certain stress is applied and the initial thickness of a crust are decisive factors in uplift and subsidence processes. From the analysis of Dewey's paper, it is possible to say that in the case of there being a previously significant thickened crust, where the extensional stresses are applied at a low deformation rate during a long period of time, extension in the base of the crust could cause average thickening of the lower crust, and not crustal thinning as would be expected.

It is proposed that the tectonic evolution for the Transamazonian orogeny, could result in crustal thickening by continuous subcontinental accretion (vertical) and consequent thinning of the lithospheric mantle (Touret 1996), and generating this way a continental magmatic arc. This model can explain both the generation of calcalkaline and tholeiitic associations and also the geological evidence described above.

GEOLOGIC EVOLUTION The geologic-geotectonic evolution proposed for the Juiz de Fora area involves extensional processes during the Transamazonian orogeny with magmatic under- and intraplating below an existing continental crust, providing the $\mathrm{CO}_{2}$-rich fluids and the excess heat necessary for granulite facies metamorphism, causing at the same time the granulitization of the base of this crust (orthogranulites of JFTD and ANDTD). The resulting anomalous heat flow would elevate the continental geotherms causing extensive partial melting and differentiation of the lower crust generating preferentially tonalitic magma, and later passing on to more granitic compositions. These magmas would ascend in the crust, reworking older segments (Archean?) in upper crustal levels. The result of this process would be a reworked, Transamazonian age crust with granulites of predominantly basic composition (gabro, leucogabbro, ultramafic rocks, mafic tonalites, mafic granulites) in the lower portions, transitional to essentially intermediary composition rocks (enderbites, charnockites, granodiorites, felsic tonalites, granites, trondhjemites) at shallow levels. Thus, in the studied area, the orthogneisses and granulites of JFTD would correspond to middle to lower portions of this reworked crust, while the hornblende orthogneisses of ANDTD would be its equivalent in upper levels at middle to upper crustal conditions.

With the evolution of the extensional process, at the final stages of the Transamazonian orogeny, a crustal thinning process, also aided by erosional thinning, resulted in rifting of the upper part of the crust, giving rise the intracratonic São João del Rei basin. Mafic dykes cutting São João del Rei basin sediments yield $1.8 \mathrm{Ga} \mathrm{Sm} / \mathrm{Nd}$ model ages (Ribeiro et al 1995). This fact suggests that the upper crustal rifting processes occurred at the final stages of the Transamazonian orogeny, in support of the hypothesis that the magmatic underplating did not generate extensional thinning of the upper crust since the beginning of this tectonic event.

After a long period of quiescence, renewed tectonic activity during the Brasiliano tectono-thermal event initiated a compressive process of continental collision, resulting in generating shear zones and thrusts, and placing side by side supracrustal rocks, the granulite basement (Juiz de Fora Complex), and the orthogneisses locally in granulite facies (Mantiqueira Complex). This collision began with vergence to NW, in the direction of the São Francisco Cráton, generating the anastomosed or lens-shaped structures in the sin-colisional stages, related to the directional phase of the deformation. In this period, widespread partial melting in the metasedimentary rocks resulted in the formation of large quantities of migmatites, granitic and charnockitic rocks. This process possibly removed large amounts $\mathrm{H}_{2} \mathrm{O}$ from the system, allowing the metasedimentary rocks to reach granulite facies.

At the final stages of Brasiliano orogeny a tectonic reversion began, generating late mylonites $\left(\mathrm{D}_{4}\right)$, pegmatites and leucogranites, that can be associated to a stage of crustal "relaxation" or orogen collapse, or even to the beginning of a new tectonic extension. It is possible that this process is related to an initial phase of a new magmatic underplating process that was later responsible for the opening of the Atlantic Ocean.

In the discussion on tectonic models accomplished in this paper, a number of doubts and uncertainties still remain. It is considered that some detailed studies, involving mineral chemistry and geochronology can generate more precise results, since it would provide subsidies to the understanding of the P-T-t evolution for the different tectonic events separately, as well as in the determination of the specific ages of episodes inside the geologic evolution presented.

Acknowledgements We thank Fundação de Amparo à Pesquisa do Estado de São Paulo (FAPESP), Conselho Nacional de Pesquisa (CNPq) and Fundação de Amparo à Pesquisa do Estado do Rio de Janeiro (FAPERJ) for financial support received during this investigations. To two anonymous referees of RBG for the critical review of the manuscript.

\section{References}

Bohlen S.R. 1991. On the formation of granulites. J. metamorphic Geol. 9:223-229.

Bohlen S.R. 1987. Pressure-temperature-time paths and a tectoniCreated on 28/02/00 15:42c model for the evolution of granulites. Journal of Geology, 95:617-632.

Clemens J.D. 1990. The granulite-granite conexion. D. Vielzeuf and Ph. Vidal (eds.) Granulite and Crustal Evolution, p. 25-36.

Dewy J.F. 1988. Extensional collapse of orogens. Tectonics, 7:1123-1139.
Duarte B.P., Nogueira J.R., Heilbron M., Figueiredo M.C.H. 1994. Geologia da região de Juiz de Fora e Matias Barbosa (MG). In: SBG, Congr. Brasil. Geologia, 38, Camboriú, Resumos Expandidos, 2:88-90.

Ellis D.J. 1987. Origin and evolution of granulites in normal and thickened crusts. Geology,

15:167-170. zine, 126:215-247. 
Heilbron M. 1993. Evolução tectono-metamórfica da seção Bom Jardim de Minas (MG) Barra do Piraí (RJ). Setor Central da Faixa Ribeira. Tese de doutorado (não publicada). IG/USP, São Paulo, 268p.

Heilbron M., Rocha A.D., silva L.G.E., Nogueira J.R., Trow R.A.J., Polônia J.A.L. 1994 Compartimentação tectônica da seção Conceição do Ibitipoca (MG) - Valença (RJ) segmento central da Faixa Ribeira. In: SBG, Congr. Brasil. Geologia, Camboriu, Resumos Expandidos, 2:55-56.

Heilbron M., Machado R., Figueiredo M.C.H. 1997. Lithogeochemistry of paleoproterozoic orthogranulites from the Rio Preto (MG) - Vassouras (RJ), Central Ribeira Belt, SE Brazil. Rev. Bras. Geoc., 27:83-98.

McGregor V.R. \& Friend C.R.L. 1997. Field recognition of rocks totally retrogressed from granulite facies: an example from Archean rocks in Paamiut region, South-West Greenland. Precambrian Research, 86:59-70.

Machado N., Valladares C.S.; Heilbron M., Valeriano C. 1996. U-Pb geochronology of the central Ribeira belt (Brazil) and implications for the evolution of the Brazilian Orogeny. Precambrian Research, 79:347-362.

Nogueira J.R. 1999. Evolução geológica dos terrenos de alto grau metamórfico da Faixa Ribeira na região de Juiz de Fora, Minas Gerais. Tese de Doutorado, IG/ UNICAMP, $190 \mathrm{p}$

Nogueira J.R., Choudhuri A., Trouw R.A.J. 1999. Fluid inclusion studies, P-T-t paths and geotectonic evolution of the granulite facies terrane of Juiz de Fora, southeastern Brazil. In: N.G.K. Murthy \& V. Ram Moham (Eds.). Proc. of the International Symposium on Charnockite and Granulite Facies Rocks. Geologists' Association of Tamil Nadu, Chennai, India. Spec. Publ. no 4, p. 317-328.

Nogueira J.R. 1994. Relações tectono-estruturais e metamórficas entre metassedimento e ortognaisses em fácies granulito na região a sudoeste de Juiz de Fora, Minas Gerais. Dissertação de Mestrado, DG/UFRJ, 187p.

Ramsay J.G. \& Huber M.I. 1987. The Techniques of Modern Structural Geology. Vol. 2: Folds and Fractures. Academic Press, London. 307p.
Ribeiro A., Trow R.A.J., Andreis R., Paciullo F.P., Valença J.G. 1995. Evolução das bacias proterozóicas e o termo-tectonismo brasiliano na margem sul do Cráton do São Francisco. Rev. Bras. Geosc., 25: 235-248.

Sandiford M.A. \& Powell R. 1986. Deep crustal metamorphism during continental extension; ancient and modern examples. Earth and Planetary Science Letters, 79:151-158.

Smellie J.L. 1994. Volcanism associated with extension at consuming plate margins. Smellie (Ed.). Geol. Soc. Spec. Publ., n ${ }^{\circ}$ XX, Oxford, UK, p.1.

Teixeira W. \& Figueiredo M.C.H. 1991. An outline of early proterozoic crustal evolution in the São Francisco Cráton, Brazil: a review. Precamb. Res. 53:1-22.

Thompson A.B. 1990. Heats, fluids and melting in granulites. D. Vielzeuf and Ph. Vidal (eds.). Granulite and Crustal Evolution, p. 37-57.

Thompson A.B. \& England P.C. 1984. Pressure-temperature-time paths of regional metamorphism II. Their inference and interpretation using mineral assemblages in metamorphic rocks. J. Petrol., 25:929-955.

Touret J.R.L. 1992.CO transfer between the upper mantle and atmosphere: temporary storage in the lower continental crust. Terra Nova, 4:87-98

Touret J.R.L. 1996. LILE depletion in granulites: myth or reality? In: D. Demaiffe (Ed.) Petrology and geochemistry of magmatic suits of rocks in the continental and oceanic crusts. Université Libre de Bruxelles. Royal Museum for Central Africa (Tervuren), p. 53-72.
Contribution IGC-181

Received March 9, 2000 Accepted for publication May 6, 2000 